\title{
Producing a village input-output table (VIOT) from household survey data: a case study of a VIOT for a rural village in northern Lao PDR
}

\author{
Soulixay Hongsakhone ${ }^{1}$, Moinul Islam ${ }^{3,4^{*}}$ (]) and Masaru Ichihashi ${ }^{1,2}$
}

\author{
*Correspondence: \\ islam.moinul@kochi-tech. \\ ac.jp \\ ${ }^{3}$ School of Economics \\ and Management, Kochi \\ University of Technology, \\ 2-22 Eikokuji, Kochi 780-8515, \\ Japan \\ Full list of author information \\ is available at the end of the \\ article
}

\begin{abstract}
In this study, a village input-output table (VIOT) is built from household survey data from a rural village in a developing country to capture the interdependency between households through their transactions in 2016. This VIOT is a simple, but useful tool for understanding the economic transactions among villagers. The main findings of this work are that lower- and middle-income households mainly depend on commodities supplied by non-poor counterparts, especially by four higher-income households, who are not only producers, but also traders of commodities in the village and play key roles in the village economy, and that the $1 \mathrm{O}$ interdependency among non-poor households is stronger than that among poor households. Additionally, this paper describes a first trial application of the VIOT method to develop economic policies with goals such as poverty reduction and trade expansion in the village.
\end{abstract}

Keywords: Village input-output table, Inter-household dependency, Economic development, Transactions

JEL Classifications: D57, R15, 132, D13, O13

\section{Introduction}

The strong human relations through trade, the exchange of goods and services between households in disadvantaged areas lead to an increasing role of economic interactions and potentially wider economic development and growth. The main purpose of this study is to make a village input-output table (VIOT) from household survey data to examine the interdependency among households through transactions in an isolated and disadvantaged village in a developing country. In doing so, we conducted household surveys in a rural village in northern Luang Prabang province, Lao PDR in 2015 and 2016 to gather all relevant data and information.

VIOT construction is simple, but it is a useful tool to know the economic transactions among villagers in the village because the information contained in such tables is useful not only for describing a circular structure of flows of major goods and money within a village, but also for revealing the effects of production in the village and providing us with directional pair data for buyers and sellers, which can be used to estimate commodity flows between households and examine the causal effects of a treatment by following

(c) The Author(s) 2021. This article is licensed under a Creative Commons Attribution 4.0 International License, which permits use, sharing, adaptation, distribution and reproduction in any medium or format, as long as you give appropriate credit to the original author(s) and the source, provide a link to the Creative Commons licence, and indicate if changes were made. The images or other third party material in this article are included in the article's Creative Commons licence, unless indicated otherwise in a credit line to the material. If material is not included in the article's Creative Commons licence and your intended use is not permitted by statutory regulation or exceeds the permitted use, you will need to obtain permission directly from the copyright holder. To view a copy of this licence, visit http://creativeco mmons.org/licenses/by/4.0/. 
a micro-econometric methodology. Thus, this VIOT is an appropriate approach and is particularly applicable for disadvantaged areas where it is often difficult to obtain socioeconomic data, such as developing countries, to fully analyze the reciprocity of rural households through their economic transactions.

By using the VIOT model, we can identify who are the key market players, sellers and buyers, as well as producers and consumers in the village. Moreover, we could explore the immobilization in a community by examining the circular structure of flows of goods and money in that society. In our opinion, we assume that households exhibiting fewer trade transactions with others tend to present lower incomes as well as minimal opportunities to obtain goods and escape from poverty, while households that frequently exhibit trade transactions with others tend to present increased opportunities to receive income and overcome poverty. Therefore, households with very frequent trade transactions with others will gain greater incomes to reduce poverty, and households exhibiting less trade or no trade transactions with others will have low incomes, leading to poverty. This VIOT method can provide basic information about this issue and can be used to form economic policies for goals, such as poverty reduction by providing information on households playing a key role in the village. Furthermore, this VIOT can be used to measure income gaps or the expansion of poverty based on the frequency of trade between households because interdependency occurs in human relationships through trade. In many rural areas in developing countries, the producers of goods, such as farmers, are also the consumers in the village, which means that each household depends on the other households for both production and their livelihood. In such areas where the same household or person has characteristics of both a producer and a consumer, the VIOT model is therefore an advantageous tool for analysis.

While classical economists such as Smith and Marx identified principles of economic development through trade and capital circulation, it is widely known that income gaps frequently emerge. Income gaps and their causes are among the most fundamental issues in economics, along with trade or the exchange of goods. The input-output (IO) model developed by Leontief has long been a useful tool for investigating interdependency among industries and key sectors in the economy. This model, therefore, was used to develop the concept of the multi-sectoral multiplier in the industrial sector, which was derived from the macroeconomic multiplier developed by Keynes. This multi-sectoral multiplier can be used as an index of the interdependency of industries. Traditionally, the IO model has been employed to relate the product flows from producer to the consumer sectors and is constructed from observed data for economic areas such as nations or regions.

Most researchers focused on IO models and their implications for the specific national, regional or international and inter-regional IO studies. Their studies have used IO analysis to evaluate economic impact of industrial sectors on a national, international and inter-regional level. There have been several types of IOTs constructed and compiled by researchers for these studies over past decades. For example, Isard (1951) described how to compile an inter-regional input-output (IRIO) table for the United States. Furthermore, Zhang et al. (2015) attempted to construct a province-level IRIO model for China for 2002, and Dietzenbacher et al. (2013) built world input-output tables (WIOTs) for 40 countries plus the rest of the world. However, this type of research on IO studies at 
bottom-up level, especially from village perspective has been rarely conducted because researchers often lack enough information and socioeconomic statistics. Moreover, survey approach and techniques are costly and time-consuming.

Few studies used rural IO information from household survey data. Taylor et al. (1996) study is one among the previous studies that used rural input-output information from the household surveys, including a social accounting matrix (SAM) and computational general equilibrium (CGE). The authors focused on the main flows of money, including income; therefore, the sector sizes of their input-output tables were relatively small, and they included only five sectors, namely farming, livestock, resource extraction, construction and village retail activities. The authors used 1982 household survey data from a major migrant-sending rural village in central Mexico to analyze the economic structure of a migrant-sending rural economy. The results showed that the production linkages within the village economy were weak, although there were strong consumption and investment linkages, especially for food and livestock. In addition, Lewis and Thorbecke (1992) employed a SAM approach to examine the economic linkages in a small regional economy in Kenya: their results showed that agricultural activities had the largest impact on income generation. Subramanian and Qaim (2009) developed a micro SAM to analyze the effects of agricultural biotechnology application on cotton production for rural households in India, using village census data from four states to analyze the income effects for large farms. Martin and Holden (2004) also built a small village SAM based on a household survey that they conducted in rural Mozambique to capture tree resources and assess the multiplier effects of charcoal production, and Agaje (2008) extended their village SAM to capture household income losses due to soil degradation. Faße and Grote (2014) developed environmentally extended village SAMs for Tanzania to model the input-output relationships among households, to examine the transactions of an entire village economy. These previous studies related to SAM applications were constructed from household survey data, but they mainly used aggregated tables with few sectors. However, A SAM approach does not necessarily include significant IO detail, and the IO structure of the SAM seems to be small and captured major accounts: production activities, factors of production, institutions including households, capital, and rest of the village.

In general, an input-output (IO) analysis is a quantitative technique for studying the interdependence of production sectors in an economy. These inter-industry linkages have been studied since the end of 1950s, with the main purpose of identifying the socalled key industries or key sectors that are essential for economic growth and development. The backward and forward linkages first introduced by Hirschman (1958) are the concept of inter-industry linkages analysis. Then, these linkages have been widely applied for interdependence analysis (see, e.g., Chenery and Watanabe 1958; Hewings and Romanos 1981; Hewings 1982: Defourny and Thorbecke 1984; Cmiel and Gurgul 2002; San Cristobal and Biezma 2006; Temurshoev and Oosterhaven 2014; Gurgul and Majdosz 2005; Gurgul and Lach 2015, 2016, 2018), etc. These studies are the main motivating thought for this study, and by following these ideas, we attempt to make use of VIOT created from our own household survey data to investigate the interdependence among households through their trade transactions in the corresponding village. This VIOT model could be an applicable method for examining inter-household dependency 
data $^{1}$ and capturing the economic structure of the village, household production, and consumption, which improves our understanding of economic interdependence and transactions among key agents in isolated villages or disadvantaged areas, allowing us to identify potential areas for development interventions, in addition to providing a helpful tool and reference for VIOT studies, for scholars conducting similar studies in the future.

The information on transactions for intermediate sales and purchases of goods and services between households in the village is the key for the VIOT construction. Theoretically, IO model follows an accounting framework in which the total receipts by sellers must balance the total expenditures by buyers. By that conversion, total output is equal to total input for each producing sector in the economy. Surprisingly, when we conducted our household survey, we investigated economic activities related to production and consumption over the previous year, and there was a gap in the balances of sales and purchases for each good in our survey data because respondents did not recall exactly how often they had sold and purchased their goods from others over the previous year. We also faced a difficulty dealing with consumption data distribution, because households did not know correctly how much they consumed each commodity they bought from others, so we had to solve problems in estimating a consumption ratio and then redistributed it in each household, this is an artificial value in consumption vector.

Our household surveys were conducted in March 2015 and March 2016 in Phonxay village, which is situated in the northeastern part of Luang Prabang province, Lao PDR, close to the border with Vietnam. It is a typical disadvantaged village and community under the poverty line in an Asian country. As of 2016, there were 124 households, which had 720 inhabitants in the village. Total annual household income is 1,705,230,000 Kip (approximately US\$213,145 at market exchange rate on 1 US dollar/8000 Kip). The average monthly per capita income is $197,365 \mathrm{Kip}$ and the major source of household income is rice, contributing $778,640,000 \mathrm{Kip}$, or $45.66 \%$ of the total annual household income, followed by non-timber forest products (NTFPs) at 428,010,000 Kip (25.10\%), livestock at 330,580,000 Kip (19.39\%), and wages and salaries at 99,630,000 Kip (5.84\%). According to our survey data, the Gini coefficient in terms of per capita income in this village is 0.6607 , which means that the market income disparity among households is extremely high measured at market prices.

The remainder of this paper is divided as follows: Sect. 2 briefly introduces the collection of relevant data from an own household survey and then a summary of those data. The conversion of household survey data to an IO framework is explicitly described in Sect. 3. A sample VIOT analysis and the relations among households are described in Sect. 4, including the total output multiplier and backward and forward linkage analyses, to examine the degree of inter-household dependency in transactions. The final section summarizes main results and provides concluding remarks.

${ }^{1}$ Our VIOT is a village-level IO model, which is like an international or inter-regional IO model, such as the Izard-type table if one considers each individual household to play the role of a country or a region. 


\section{Household survey data in the targeted village}

We targeted a small rural village called 'Phonxay village' which is located in northeastern part of Ngoi district of Luang Prabang province, Lao PDR (Fig. 1). This village is a typical disadvantaged community of an Asian country, under the poverty line. The data and information were collected through direct interviews and questionnaires. We employed five local government officials from the Trade and Industry Office of the Ngoi district of Luang Prabang province who were well known to the local people, and the field survey staffs were trained. All 124 household units in the village were asked to provide all relevant information and data from February 29 to March 18, 2016. The collected data focused on household monetized spending for both food and non-food items as well as the various possible sources of income received by all household members. Relevant data and information, such as the demographic characteristics of the population, household debt, and borrowing (loans) as well as domestic remittances, were also included. This information revealed the households' major sources of income and expenditures over the past twelve months, which included products bought and sold, home-productions and products given away to other households, and products received from other households within the village. Transaction information for households is an essential component in constructing a VIOT because it corresponds to intermediate input and intermediate demand in the table. The income and expenditure values used herein are based on local market prices (village prices) expressed in nominal terms (2015).

This village was selected by the local government of Luang Prabang province, Lao PDR, in response to our asking which village was the most challenged regarding economic development in the district or province. This village's inhabitants come from the Khmu ethnic group, which has a unique culture and dialect. The village was forested in the past and has a total area of 560 hectares. It is situated in the northern part of the Ngoi district, Luang Prabang province, and its households are distributed close to each other along the main road, which passes through the village to the Phonthong district of Luang Prabang province and the Laos-Vietnam border (Fig. 1). The village is situated at an altitude between 1000 and $1800 \mathrm{~m}$ above sea level. It is separated by approximately $50 \mathrm{~km}, 70 \mathrm{~km}$, and $200 \mathrm{~km}$ from the Laos-Vietnam border market in the Phonthong district, the Ngoi district market and the markets of the capital city of the Luang Prabang province, respectively. The surrounding forests are the major source of food and income generation for this village.

In the 1970s, many households in the study area were both opium producers and consumers (2010 report for the Ngoi district). Several people, in particular, men smoked opium and became addicted. As a result, they faced serious employment, social and health problems. In the early 2000s, the government of Laos enacted strong policies to eliminate the cultivation of the opium poppy. The villagers subsequently transformed their income and economic activities by converting forests into farmland, growing more rice and other field crops, raising domestic animals and selling them, cutting firewood, harvesting timber, and selling various NTFPs.

Sticky rice is the staple food in the village; most households also have a small vegetable garden and grow crops including cotton and sugarcane, but they plant only in small quantities for personal use. Additionally, the villagers raise chickens, ducks, pigs, and goats as well as buffaloes and cows for their own consumption and for plowing the fields. 


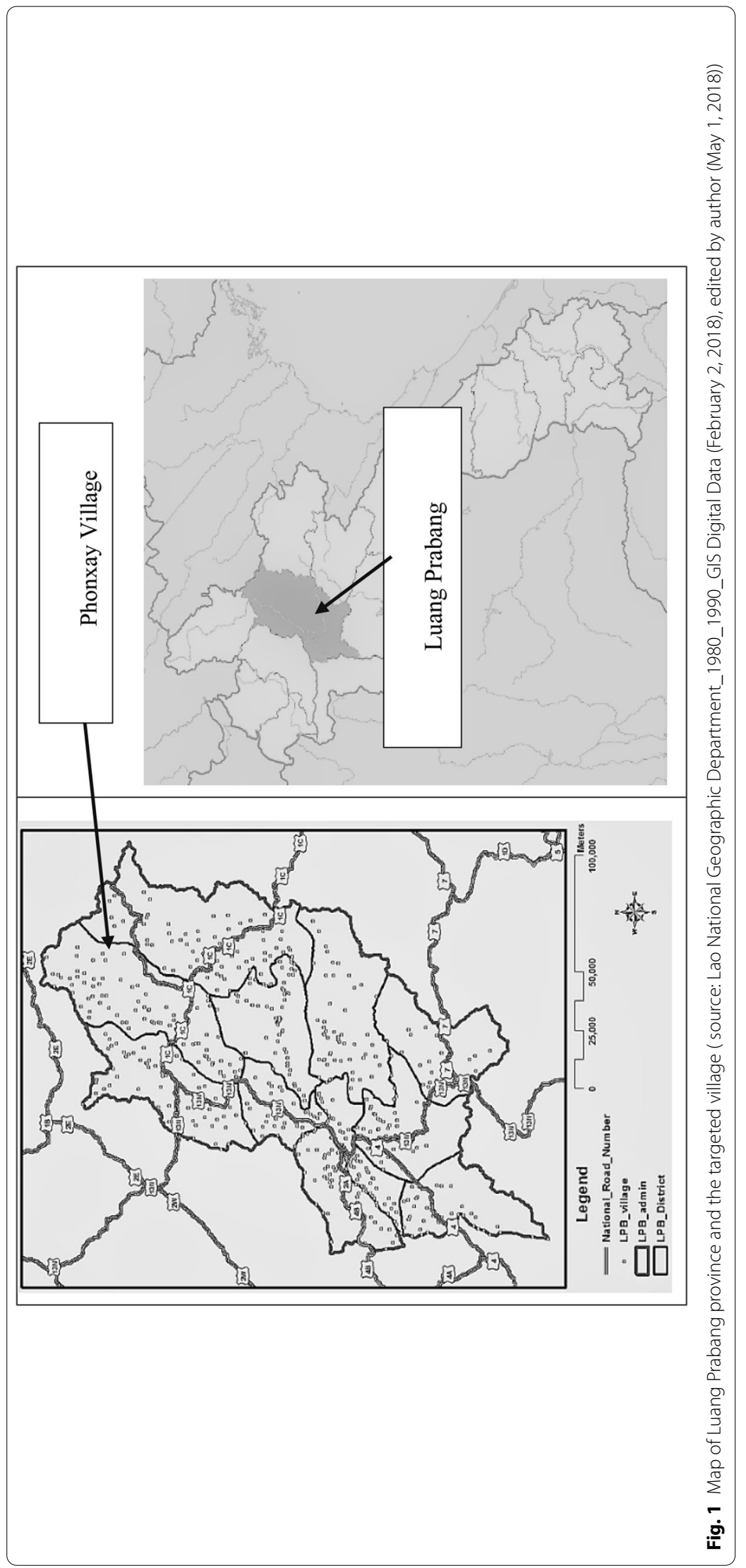


In general, households in the village are largely self-sufficient, growing their own food and making their own tools, and consuming their own products, however, they can trade any surplus for such basic items as soap, kerosene, medicine, and kitchen or household goods that are mainly imported goods. The households cooperate informally, especially in agricultural work, and mutual assistance and labor (money and products) exchange are organized based on exchanges among families across years for transplanting, harvesting, and threshing. The village's population has been growing, and prime land for agricultural use is now becoming scarce in its immediate vicinity. In addition, wild areas have been degraded, and access to natural resources, such as bamboos and other NTFPs have gradually deteriorated. Bamboo shoots, mushrooms, fruits, medical or culinary roots, and leaves are gathered in the forest according to the season.

After the Lao PDR established its independence in 1975, villagers began to travel to regional population centers in search of work and to earn a daily wage as supplemental income. Domestic trade, social networks, and transportation among the villagers are very limited and small in scale. The Lao government adopted the New Economic Mechanism in 1986, and privately managed general stores and periodic markets began to appear in rural areas that had, previously specialized in subsistence farming. Since then, the products from this village have mostly consisted of rice, domestic animals, and agroforest products such as benzoin, cardamom, stick lac, and other NTFPs. Trade transactions only take place through Lao merchants who act as middlemen between mountainous villages (Khmu traders) and lowland ethnic Lao villages (Lao Loum merchants). These middlemen transport agroforest products and some surplus harvested rice to ethnic Lao merchants in the lowlands or city markets in the Ngoi district, in exchange for iron products such as farming implements and sharp tools including medicines, etc. There was only one trader of agroforest products in the village in the 2000s. However, there are now four local traders who purchase these products and sell them to merchants in Luang Prabang via the Ngoi district and NamBak district; some of these products are also sold to Vietnam, Thailand, and China.

Table 1 shows a summary of the socio-economic characteristics of Phonxay village in 2016. Our survey work showed that the female population accounts for $51 \%$ of the total population, while males represent $86 \%$ of all household heads in the village. The average household size is 5.8 (including all members in the family). Approximately $25 \%$ of all household heads have no formal education. Approximately $8 \%$ of all households are landless. Female labor accounts for over half (51\%) of the total labor force in the village.

Table 2 presents the sources of household income in Phonxay village. The survey shows that the total annual household income of the village is 1,705,230,000 Kip (approximately US\$ 213,145$).^{2}$ The primary source of income is rice, which contributes $778,640,000$ Kip or $45.66 \%$ of the total annual household income; followed by NTFPs, which contributes 428,010,000 Kip (25.10\%); livestock, contributing 330,580,000 Kip (19.39\%); and wages and salaries, contributing 99,630,000 Kip (5.84\%). The average monthly per capita income in this village is $197,365 \mathrm{Kip},{ }^{3}$ which is above the Lao national poverty line

\footnotetext{
2 The exchange rate between the Lao PDR Kip and The US dollar at the time of the study (at market price on March 20, 2016) was 8000 Kip/U.S dollar.

3 The Prime Minister of the Lao PDR: Decree on Poverty and Development Standard 2010 to 2015, No. 285/PO, dated October 13, 2009, proposed a standard for measuring poverty at the individual level with three levels: (1) the nation: 192,000 Kip/person/month; (2) rural areas: 180,000 Kip/person/month; and (3) urban areas: 240,000 Kip/person /
} 
Table 1 Socio-economic characteristics of the study village (2016). Source: author and Household Survey Data, March 8, 2016

\begin{tabular}{lcllcl}
\hline Characteristics & Frequency & Percentage (\%) & Characteristics & Frequency & Percentage (\%) \\
\hline Total population & 720 & 100 & & & \\
Female & 368 & 51.12 & HH size & 124 & 100 \\
Male & 352 & 48.88 & $3-5$ & 64 & 51.61 \\
Gender of HH head & 124 & 100 & $6-8$ & 57 & 45.96 \\
Female & 17 & 13.7 & $9-12$ & 3 & 2.43 \\
Male & 107 & 86.3 & Land ownership & 124 & 100 \\
HH head status & 124 & 100 & Owned and operated & 114 & 91.93 \\
Married & 107 & 86.3 & Borrowed and lent & 10 & 8.06 \\
Widowed & 17 & 13.7 & Labor force & 272 & 100 \\
Age of HH head & 124 & 100 & Male & 132 & 48.52 \\
$20-30$ & 10 & 8.06 & Female & 140 & 51.48 \\
$31-40$ & 30 & 24.19 & Occupation & 124 & 100 \\
$41-50$ & 31 & 25 & Farming & 122 & 98.38 \\
$51-60$ & 35 & 28.23 & Civil Service & 2 & 1.62 \\
$>60$ & 18 & 14.52 & Education Level & 124 & 100 \\
Farm size (Hectares) & 124 & 100 & No formal education & 31 & 25 \\
$0.0-1.0$ & 78 & 62.9 & Primary education & 77 & 62.1 \\
$1.0-2.0$ & 20 & 16.12 & Secondary education & 15 & 12.1 \\
$>2$ & 26 & 20.98 & Higher education & 1 & 0.8 \\
\hline
\end{tabular}

Table 2 Main sources of household income in Phonxay village (2016). Source: Field survey data, March 8, 2016

\begin{tabular}{lccc}
\hline Source of income & \multicolumn{2}{l}{ Household income (unit: 1 Kip) } \\
\cline { 2 - 4 } & Annual & Per capita & Share (\%) \\
\hline Rice & $778,640,000$ & 90,120 & 45.66 \\
NTFPs & $428,010,000$ & 49,538 & 25.10 \\
Livestock & $330,580,000$ & 38,262 & 19.39 \\
Wages and salary & $99,630,000$ & 11,531 & 5.84 \\
Remittances & $20,350,000$ & 2,335 & 1.19 \\
Other & $48,020,000$ & 5,558 & 2.82 \\
Total & $1,705,230,000$ & 197,365 & 100 \\
\hline
\end{tabular}

for rural areas (180,000 Kip/person/month or approximately US\$22.5/person/month). According to our calculation, the Gini coefficient of the per capita income in this village is 0.6607 , which indicates that market income disparity among households is extremely high measured at market prices.

A unique characteristic of this village is that the highest-income households in the village, consisting of four families designated $\mathrm{HH} 121$ to HH124, work not only as farmers, but also as traders of products derived from other households. They obtain their profits 
Table 3 Prices of each product in the targeted village (2015). Source: Household Survey Data (Phonxay Village Office), March 8, 2016

\begin{tabular}{|c|c|c|c|}
\hline \multirow[t]{2}{*}{ Products } & \multicolumn{2}{|c|}{ Based on year 2015} & \multirow[t]{2}{*}{ Unit } \\
\hline & Village prices $^{\mathrm{a}}$ & Market prices $^{\mathbf{b}}$ & \\
\hline Rice & 2500 & 5000 & $\mathrm{Kip} / \mathrm{Kg}$ \\
\hline Other crops & 3000 & 5500 & $\mathrm{Kip} / \mathrm{Kg}$ \\
\hline Cattle & 63,000 & 65,500 & $\mathrm{Kip} / \mathrm{Kg}$ \\
\hline Buffaloes & 60,000 & 64,500 & $\mathrm{Kip} / \mathrm{Kg}$ \\
\hline Goats & 35,000 & 38,500 & $\mathrm{Kip} / \mathrm{Kg}$ \\
\hline Pigs & 37,000 & 40,500 & $\mathrm{Kip} / \mathrm{Kg}$ \\
\hline Duck & 45,000 & 65,000 & $\mathrm{Kip} / \mathrm{Kg}$ \\
\hline Chicken & 30,000 & 36,000 & $\mathrm{Kip} / \mathrm{Kg}$ \\
\hline Bamboo shoots & 6000 & 10,000 & $\mathrm{Kip} / \mathrm{Kg}$ \\
\hline Broom grass & 6500 & 9000 & $\mathrm{Kip} / \mathrm{Kg}$ \\
\hline PongPeng (herbal roots) & 12,000 & 15,000 & $\mathrm{Kip} / \mathrm{Kg}$ \\
\hline Rattan shoots & 6500 & 10,000 & $\mathrm{Kip} / \mathrm{Kg}$ \\
\hline PeukMeuk (tree bark) & 7000 & 9500 & $\mathrm{Kip} / \mathrm{Kg}$ \\
\hline
\end{tabular}

a *Village prices information are collected from the Phonxay village office; these prices are based on the agreement between farmers and buyers in the village yearly meeting, September 23, 2015

b Market prices information are collected from the Trade Office of Ngoi District, Luang Prabang Province. These prices are based on 2015 prices

Table 4 Household income level in the targeted village (2016). Source: Field survey data, March 8, 2016

\begin{tabular}{llll}
\hline Income level (Kip) & No. of household & Share (\%) & Wealth status \\
\hline$<50,000$ & $44(1-44)$ & 35.48 & Poorest \\
$50,001-179,999$ & $67(45-111)$ & 54.03 & Poor $^{\text {Non-poor }}$ \\
$180,000-999,999$ & $9(112-120)$ & 7.26 & Non $^{a}$ \\
$>1,000,000$ & $4(121-124)$ & 3.23 & Rich \\
Total & 124 & 100 &
\end{tabular}

a Represents a household with an average monthly per capita income $>180,000 \mathrm{Kip}$, Which is above the Lao national poverty line for rural areas (2015)

from the sale of products outside the village at market prices, while other households obtain money from selling wholesale products to these four families at village prices, referred to as the "agreed price". The price of each product in the village is shown in Table 3. The village prices and agreed prices listed in the table were obtained from the village office based on the agreement between farmers and buyers in the yearly village meeting, and market price data were obtained from the Trade Office of the Ngoi district. The gap between market prices and village prices is a substantial source of profit for the four families, and this is the fundamental structure that causes income inequality in the village.

Table 4 presents household income levels in the targeted village based on the Lao National Poverty and Development Standard (2010-2015). This classification designated 44 households as the poorest group, with an average monthly per capita income of less than 50,000 Kip; 67 households as the poor group, with an average monthly per capita income between 50,001 and 179,999 Kip; nine households as the non-poor group, with 
Table 5 Sources of household income by group in the targeted village (2016). Source: Field survey data, March 8, 2016

\begin{tabular}{|c|c|c|c|c|c|c|c|c|c|c|}
\hline \multirow[t]{2}{*}{ Income source } & \multicolumn{2}{|c|}{ All $\mathrm{HH}(\mathrm{N}=124)$} & \multicolumn{2}{|c|}{$4 \mathrm{HH}(\mathrm{N}=4)$} & \multicolumn{2}{|c|}{$\begin{array}{l}\text { Non-poor } \\
(\mathrm{N}=9)\end{array}$} & \multicolumn{2}{|c|}{ Poor $(\mathrm{N}=64)$} & \multicolumn{2}{|c|}{ Poorest (44) } \\
\hline & Value & (\%) & Value & $(\%)$ & Value & (\%) & Value & (\%) & Value & $(\%)$ \\
\hline Rice & 778.64 & 45.66 & 706.32 & 57.83 & 25.19 & 20.94 & 43.93 & 17.09 & 8.30 & 7.79 \\
\hline NTFPs & 428.01 & 25.10 & 326.13 & 26.70 & 13.06 & 10.86 & 60.93 & 23.71 & 32.80 & 30.79 \\
\hline Livestock & 330.58 & 19.39 & 185.15 & 15.16 & 72.57 & 60.33 & 59.33 & 23.08 & 13.53 & 12.70 \\
\hline Wages and salary & 99.63 & 5.84 & 0 & 0 & 7.50 & 6.23 & 64.52 & 25.10 & 27.61 & 25.92 \\
\hline Remittances & 20.35 & 1.19 & 0 & 0 & 0.20 & 0.17 & 19.65 & 7.65 & 20.50 & 19.24 \\
\hline Other $^{a}$ & 48.02 & 2.82 & 3.77 & 0.31 & 1.77 & 1.47 & 8.67 & 3.37 & 3.80 & 3.57 \\
\hline Total income & 1705.23 & 100 & 1221.37 & 100 & 120.29 & 100 & 257.03 & 100 & 106.54 & 100 \\
\hline
\end{tabular}

a Includes agricultural land lent and crops income

an average monthly per capita income of more than 180,000 Kip; and the remaining four of the 124 households in the study village as the rich group, with an average monthly per capita income of over 1,000,000 Kip.

Households that belong to the same income group are assumed to exhibit similar livelihoods with respect to income-generating activities, sources of income, income levels, and market participation. Table 5 identifies the sources of household income in the four groups in the village. The poorest and poor households obtained their incomes from selling NTFPs and from wages and salaries (labor services), whereas the non-poor and rich households primarily received income from livestock and rice production, respectively.

Figure 2 shows the poor and the rich households in the village as of 2016. The households (HHs) numbered 121-124 represent rich households, with a monthly income per capita of a million or more Kip per person. The HHs numbered 112-120 are the non-poor households, with a monthly income per capita of more than 180,000 and less than 1 million Kip. The HHs numbered 45-111 are the poor households, with a monthly income per capita of 50,001-179,999 Kip. Finally, the HHs numbered 1-44 are the poorest households, with a monthly income per capita of less than 50,000 Kip.

Most of the expenditures of individual households were associated with food consumption, especially rice. Table 6 indicates that 35\%,32\%, and $27 \%$ of the total expenditures in the poorest group, poor group and non-poor group, respectively, were allocated to food and rice, whereas $69 \%$ of the total expenditures of the four rich households were allocated to non-food items, such as cars, trucks and motorbikes for their businesses purpose.

In general, total sales should be equal to total purchases in the village product transactions in our VIOT. However, we could not capture all sales because most households were reluctant to provide information about certain sales, which were an important part of the income of each household in the village. Conversely, we were able to obtain relatively complete information on purchases, which represented the main component of household expenditures (Table 7). Therefore, we assumed that the information about the purchases of goods and services for each household was enough and reliable for VIOT construction. Table 8 shows the share of each product in the total production of the village. We found that rice production accounted for $28.25 \%$ of the total production in the village, cattle and buffaloes (48.48\%) and NTFPs (14.18\%). 


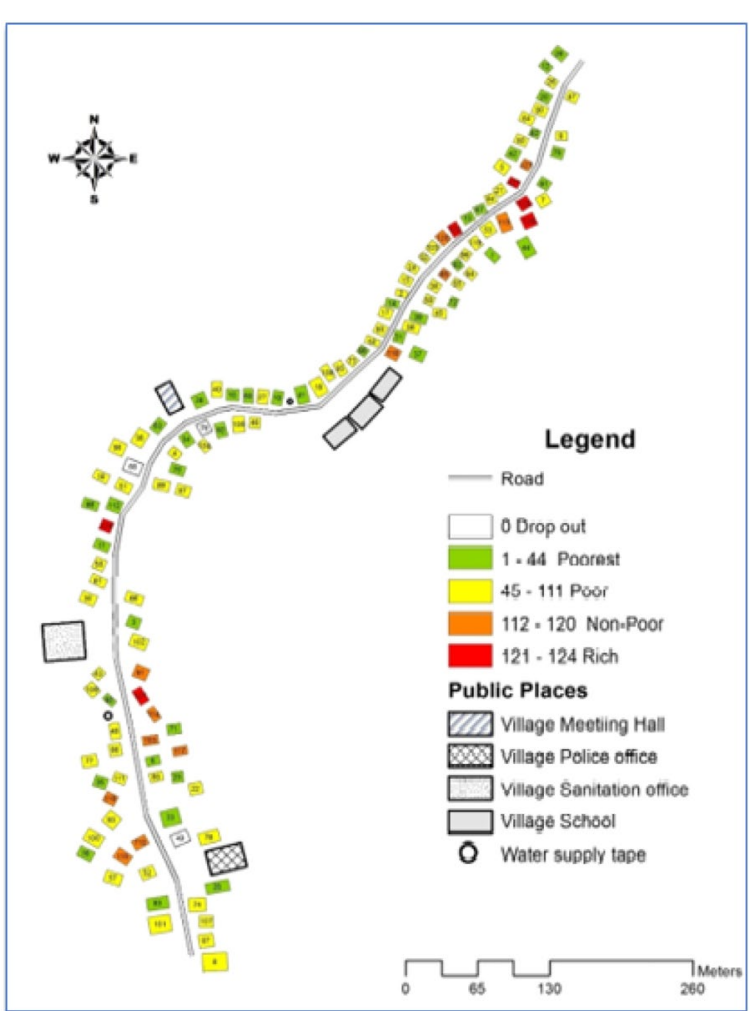

Fig. 2 Individual households in the targeted village (2016). This map was drawn by authors when conducting the household survey, March 2016

Table 6 Total household expenditures by household groups in the village (1 million Kip). Source: Field survey data, March 8, 2016

\begin{tabular}{|c|c|c|c|c|c|c|c|c|c|c|}
\hline \multirow[t]{2}{*}{ Products } & \multicolumn{2}{|c|}{ Total (124) } & \multicolumn{2}{|c|}{ Rich (4) } & \multicolumn{2}{|c|}{ Non-poor (9) } & \multicolumn{2}{|c|}{ Poor (67) } & \multicolumn{2}{|c|}{ Poorest (44) } \\
\hline & Total & (\%) & Total & (\%) & Total & (\%) & Total & (\%) & Total & $(\%)$ \\
\hline Livestock & 37.41 & 2.2 & 8.97 & 2 & 4.95 & 4.32 & 14.67 & 2.09 & 8.82 & 2.02 \\
\hline NTFPS & 6.8 & 0.4 & 0.45 & 0.1 & 0.63 & 0.55 & 3.12 & 0.44 & 2.61 & 0.6 \\
\hline Crops (rice) & 446.22 & 26.22 & 38.4 & 8.57 & 31.13 & 27.14 & 223.06 & 31.77 & 153.64 & 35.14 \\
\hline Food & 299.2 & 17.58 & 18.5 & 4.13 & 22.6 & 19.71 & 151.35 & 21.55 & 106.75 & 24.42 \\
\hline Clothing & 81.6 & 4.79 & 5 & 1.12 & 5.5 & 4.8 & 40.4 & 5.75 & 30.7 & 7.02 \\
\hline Education & 64.4 & 3.78 & 5.1 & 1.14 & 5.1 & 4.45 & 31.95 & 4.55 & 22.25 & 5.09 \\
\hline Health & 140 & 8.23 & 42.9 & 9.58 & 13.8 & 12.03 & 44.7 & 6.37 & 38.6 & 8.83 \\
\hline Land tax & 21.1 & 1.24 & 1.13 & 0.25 & 1.65 & 1.44 & 11.1 & 1.58 & 7.23 & 1.65 \\
\hline Electricity & 19 & 1.12 & 0.99 & 0.22 & 1.57 & 1.37 & 9.8 & 1.4 & 6.64 & 1.52 \\
\hline Drinks & 14.3 & 0.84 & 2.3 & 0.51 & 0.75 & 0.65 & 6.9 & 0.98 & 4.35 & 0.99 \\
\hline Vehicles & 316 & 18.57 & 311 & 69.44 & 0 & 0 & 5 & 0.71 & 0 & 0 \\
\hline Loans & 173.03 & 10.17 & 0 & 0 & 20.5 & 17.88 & 122.45 & 17.44 & 30.08 & 6.88 \\
\hline Others & 82.85 & 4.87 & 13.1 & 2.93 & 6.5 & 5.67 & 37.7 & 5.37 & 25.55 & 5.84 \\
\hline Total & 1701.92 & 100 & 447.84 & 100 & 114.68 & 100 & 702.2 & 100 & 437.21 & 100 \\
\hline
\end{tabular}


Table 7 Product transactions in the village input-output table (unit: $1000 \mathrm{Kip}$ ). Source: Field survey data, March 8, 2016

\begin{tabular}{llllllll}
\hline All products & Sales & Purchases & $\begin{array}{l}\text { Import/ } \\
\text { inflow }\end{array}$ & $\begin{array}{l}\text { Export/ } \\
\text { outflow }\end{array}$ & Consumption & Investment & $\begin{array}{l}\text { Giving } \\
\text { in kind }\end{array}$ \\
\hline Rice & 72,325 & 629,265 & 354,595 & 706,319 & 318,595 & 16,050 & 2475 \\
Other crops & 8530 & 45,329 & 25,480 & 18,018 & 67,079 & 3730 & 0 \\
$\begin{array}{c}\text { Cattles/buf- } \\
\text { falo }\end{array}$ & 57,900 & 89,930 & 7500 & 178,000 & 13,830 & 790,000 & 58,500 \\
Goat/pigs & 1200 & 112,650 & 4900 & 70,775 & 19,940 & 171,610 & 0 \\
Duck & 5280 & 20,050 & 3640 & 12,200 & 15,750 & 5265 & 900 \\
Chicken & 12,000 & 45,700 & 4525 & 21,190 & 15,705 & 43,205 & 0 \\
Bamboo & 34,430 & 47,383 & 1430 & 53,150 & 7192 & 0 & 0 \\
shoots & & & & & & & 0 \\
Broom grass & 51,735 & 71,275 & 158,450 & 300,500 & 0 & 0 & 0 \\
Other NTFPs & 23,210 & 46,420 & 21,945 & 100,110 & 0 & 0 & 0 \\
Others & 0 & 0 & 467,015 & 0 & 82,850 & 0 & 0 \\
Total & 266,610 & $1,108,002$ & $1,049,480$ & $1,460,262$ & 540,941 & $1,029,860$ & 61,875 \\
\hline
\end{tabular}

All values were expressed in Lao Kip. Crops include sweet corn, chili pepper, eggplants, and cucumber. NTFPs such as tree bark, rattan shoots, and herbal roots. Others include farm inputs, e.g., tools, equipment, fertilizer, motor vehicles and home appliances

Table 8 Total production in the study village (unit: 1000 Kip). Source: Field survey data, March 8, 2016

\begin{tabular}{lcccc}
\hline All products & Self-production (1) & Purchases (2) & $\begin{array}{l}\text { Total } \\
\text { production = (1) + (2) }\end{array}$ & Share (\%) \\
\hline Rice & 131,904 & 629,265 & 761,169 & 28.25 \\
Other crops & 26,548 & 45,329 & 71,877 & 2.67 \\
Cattles/buffaloes & $1,000,800$ & 89,930 & $1,090,730$ & 40.48 \\
Goats/pigs & 145,975 & 112,650 & 258,625 & 9.60 \\
Duck & 15,705 & 20,050 & 35,755 & 1.33 \\
Chicken & 41,875 & 45,700 & 87,575 & 3.25 \\
Bamboo shoots & 45,959 & 47,383 & 93,342 & 3.46 \\
Broom grass & 122,510 & 71,275 & 193,785 & 7.19 \\
Other NTFPs & 54,955 & 46,420 & 101,375 & 3.76 \\
Total & $1,586,231$ & $1,108,002$ & $2,694,233$ & 100 \\
\hline
\end{tabular}

Others* are mainly imported products outside the village

\section{Converting the household survey to an 10 framework}

Each household in the study village primarily produced at least one of the following nine goods: (1) rice, (2) crops such as sweet corn, maize, chili pepper, eggplant, and cucumber, (3) cattle including buffaloes, (4) goats including pigs, (5) ducks, (6) chickens, (7) bamboo shoots, (8) broom grass, and (9) NTFPs such as tree bark, rattan shoots and herbal roots. In addition to these products, we established 'others' as a sector (10) that included goods such as durable goods (motor vehicles), fertilizer, feed for livestock and other household equipment. These items are typically imported goods from outside the village. As a result, our VIOT consisted of nine plus one item from 124 households' major products transactions and formed a $1240 \times 1240$ matrix size in this paper. 
Our household survey data include information on the volume of products sold to or bought from other households, goods given away or donated to and received from others, and basic information such as family members, production activities, income, and expenditures. The exchange information among households corresponded to intermediate input and final demand in the VIOT. However, it should be noted that the total number of transactions between households does not include information about how many products were used as intermediate inputs and how many were consumed as final goods. Therefore, we calculated a consumption ratio using the initial survey data for each household. This consumption is total output divided by intermediate consumption and primary inputs used in each household's production. Based on this ratio, the transactions between households under each category are allocated to intermediate inputs and consumption.

Final demand consisted primarily of consumption (C), investment (I), and outflow/ exports (E), and we added one column labeled "giving in kind" (G) to others. Among the categories of final demand, consumption (C) represents the commodities consumed by each household, including in-kind goods. The intersection of consumption and inflows/ imports in the VIOT shows the final consumption as inflows from outside the village (e.g., food, and drink, education, sanitary (healthcare) services, and clothes). Investments (I) represent the acquisitions of inventory and buildup of the transactions in each household. The intersection of inflows/imports and investments in the VIOT represents the investments as inflows from outside the village (e.g., cars, trucks and motorbikes, which are imported goods). Outflow/Exports (E) represent the value of sales for each household to people outside the village. For example, rice, cattle, chicken and NTFPs are sold at the weekly market outside the village; these products are treated as exports for the remainder of the village. Inflow/Import (IM) is the value of purchases for each household from people outside the village, but this category is recorded and shown in the table as a new row. This approach means that the VIOT is an Izard-type or non-competitive import type of IO table, which is like an international or inter-regional IO table, because the inflows and imports are treated as a vector row and are excluded from domestic transactions when constructing the VIOT.

In a typical IO table, indirect taxes (less the subsidies for each product and the depreciation cost) are placed in the value-added area. Due to the lack of this type of information in our VIOT, we include wages and salaries, loans, remittances or gifts which are money transfers, and surplus and adjustment rows in this area. Wages and salaries are the compensation paid to other households to produce each good, which means that these are payments or costs, not received money. Loans and remittances or gifts are also included in the value-added area of the table. This information represents monetary transfers from relatives outside the village; it is typically not included in an input-output table because these transfers are not value adding inputs or production activities. However, we added this information to the table to understand the quantity of monetary inflows for each household. On the other hand, in the value-added area, the surplus is a household's earnings for each good, including earnings via labor services for other households to produce goods, which is not included in the other categories. Such labor services for other households sometimes contribute to production and can be considered a type of earnings/surplus for each household. Therefore, in our table, labor is included in the 


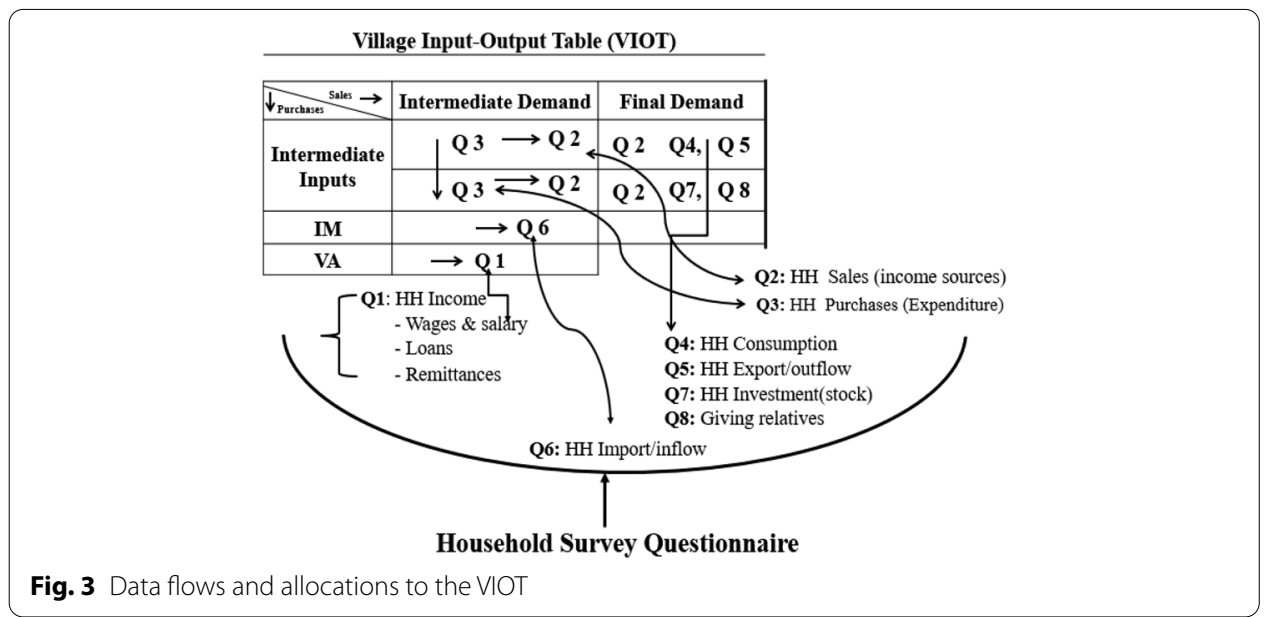

surplus row as income in addition to the surplus from producing each good. This surplus is a difference between the total household output and the sum of the total intermediate inputs, inflows/imports, and wages and salaries. Based on this definition, we calculate the surplus values and present them as a row vector in the value-added area. Finally, we create an adjustment row in the value-added area to balance the table. This adjustment consists of an artificial row derived from the total output minus the total intermediate input plus the value-added section.

All relevant information obtained from the household survey is allocated in the VIOT. In theory, data flows in the VIOT, especially material flows and monetary flows can be expressed as follows:

Self-production + Purchases + Inflow $/$ Import $=$ Sales + Consumption + Outflow $/$ Export + Investment. ${ }^{4}$

The term "Self-production" indicates commodities produced and consumed by households. "Purchases" are goods or commodities bought from other households, including intermediate inputs and final goods. "Inflow/imports" mainly represent commodities bought from outside the village. The "Sales" are commodities sold to other households and not own-use production, including intermediate inputs and final goods "Consumption" represents commodities consumed by each household, including in-kind goods. "Outflow/exports" represent commodities sold outside the village. "Investment" is the acquisition of capital stock or buildup of inventories of commodities.

Figure 3 shows the household data flows and their allocation in the VIOT. The sales of each household to other households and outside the village (Q2) are allocated to the intermediate inputs (along the main diagonal matrices) and final demand (consumption, investment, and export). $\mathrm{HH}$ is the unit of analysis and the diagonal transaction represent the intermediate demand of the input from their own production. The purchases of each household from other households (Q3) are allocated to intermediate inputs along the main diagonal line in each row of the VIOT. Q4, Q5, Q7 and Q8 are directly allocated to the final demand. The imports and inflows of each product to each household

\footnotetext{
${ }^{4}$ As a similar macroeconomic balance, we use the following equation, which includes only value added: Production + Inflow/Import $=$ Consumption + Outflow/Export + Investment
} 
from outside the village $(\mathrm{Q} 6)$ are allocated to the intermediate inputs and final demand of the VIOT. Q1, which includes wages, salaries and remittances as well as loans, forms part of the household income and money transfer from outside the village and is allocated to the value-added row vector in our VIOT.

The construction of the VIOT is illustrated in Tables 9 and 10. The outline of the table is similar to the international or regional input-output table; it is outlined by product type and contains all 124 households, ranked from poorest to richest (HH1 to HH124), with the top 10 goods, as described above.

\section{Sample VIOT analysis and relations among households}

All transactions at village prices and market prices are recorded in thousands (1000) of Kip, as illustrated in Table 10. This table was constructed using detailed household survey data and shows the outline of the VIOT for Phonxay village, with 1240 sectors. Each household is assumed to be able to produce at least one of 10 products, as described above.

The Leontief inverse matrix can then be derived and computed from the following simple equation:

$$
\mathbf{X}=\mathbf{A X}+\mathbf{F} .
$$

By employing a $1240 \times 1240$ transaction matrix table of the VIOT (from Table 9), the technical coefficients are calculated from the values taken from the matrix of transactions divided by total input, respectively. Solving the above expression for total output $\mathbf{X}$ we get:

$$
\mathbf{X}=(\mathbf{I}-\mathbf{A})^{-\mathbf{1}} \mathbf{F}
$$

where $(\mathbf{I} \mathbf{- A})^{-\mathbf{1}}$ is known as the Leontief inverse matrix or the interdependence coefficients; matrix $\mathbf{A}$ is known as the input coefficient matrix; and $\mathbf{I}$ is the $1240 \times 1240$ identity matrix. $\mathbf{F}$ is the compositions of goods and services that have gone to final demand sectors of households, including goods and services domestically produced and of those imported directly from outside the village. These imported products are direct allocation into the value-added row vector in the IO table. However, the imported products do not belong to the VA sector, but are treated as exogenous sectors. We, therefore, can employ Eq. (2) to calculate the Leontief inverse matrix because our VIOT is an Isard-type table, and we do not need to calculate the import matrix because the inflows and imports are not village production, and recorded outside domestic transactions when constructing the VIOT.

An additional useful interpretation of the transaction table is the measure of economic linkages within the village economy, highly linked household economies tend to be more self-sufficient in production and to rely less on outside sources for its inputs. The degree of interdependency among households on sales and purchases of goods and services in the village can be obtained by analyzing the values of the transaction matrix table. Generally, larger values indicate a tightly linked economy, whereas smaller values indicate a more open economy or depend somewhat on outside sources for their inputs and production. 


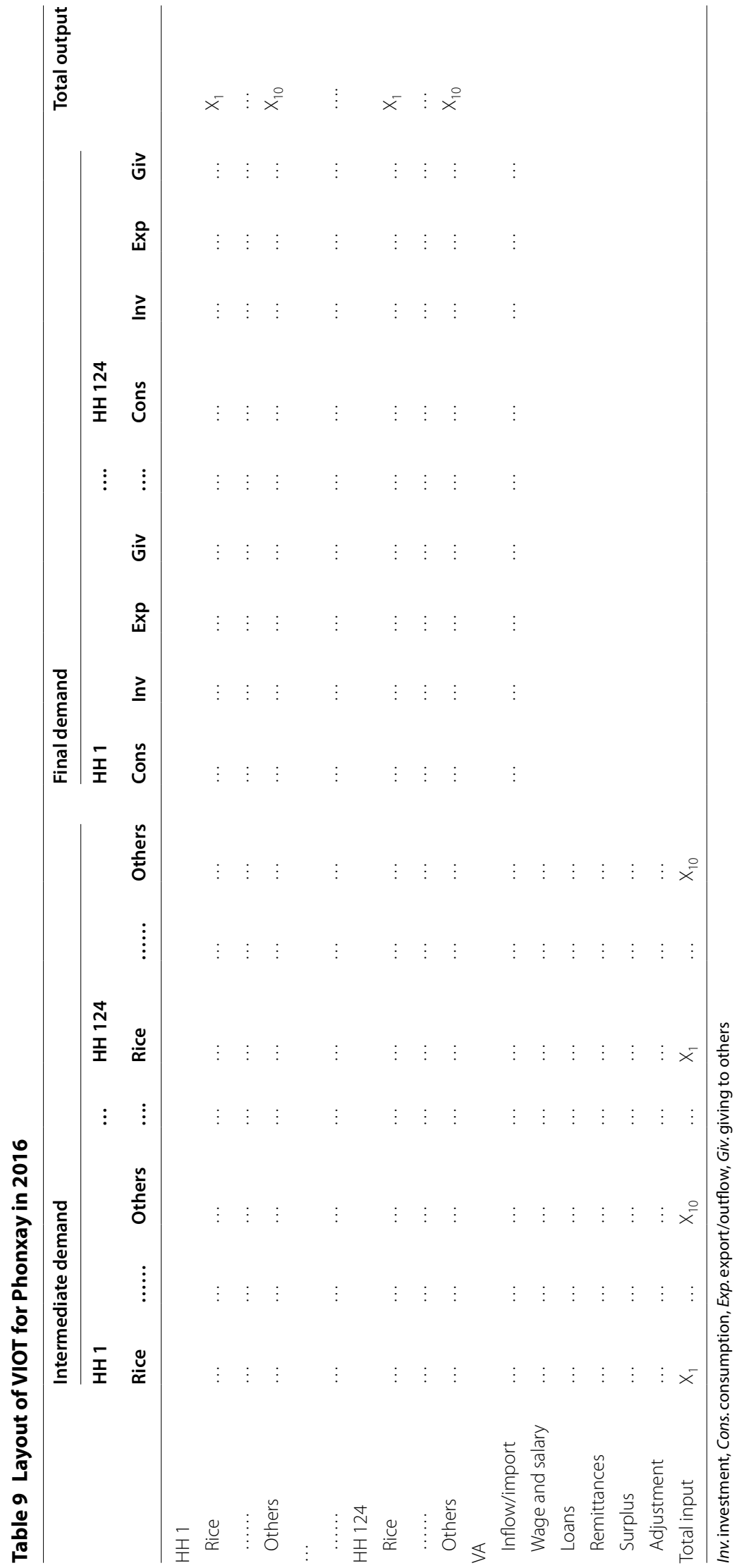


This study does not directly compute the Leontief inverse matrix from matrix $A$ because, for example, we found that the total output of some products (e.g., chicken) was equal to the total input of the same product (chicken), which results in the same values of coefficients. To solve this problem, we replace this coefficient with 0.90 . We assume that if each household receives a $10 \%$ surplus for a product, then the Leontief inverse matrix can be computed. As a result, this Leontief inverse matrix table provides the same or artificial values for backward and forward linkage estimation. ${ }^{5}$

Furthermore, the IO analysis offers two distinctive results for each analyzed sector, namely, backward linkages and forward linkages. First, the backward linkages used to present the internal transactions, showing that the increase in the total production of sector $j$ increases the demand of sector $j$ for inputs from the rest of the economic sectors, while forward linkages present the inter-sectoral transactions, showing that an increase in total production of sector $j$ increases its total supply to the rest of the economic sectors that are using the product of sector $j$ as an input in the production process. In this study, we present the backward and forward linkages for each household by each product. According to this definition, backward and forward linkages can be computed by the following formula:

$$
\begin{aligned}
\mathrm{BL}(d)_{j} & =\frac{\sum_{i=1}^{n} b_{i j}}{\frac{1}{n} \sum_{k=1}^{n}\left(\sum_{i=1}^{n} b_{i k}\right)}, \\
\mathrm{FL}(d)_{i} & =\frac{\sum_{j=1}^{n} b_{i j}}{\frac{1}{n} \sum_{k=1}^{n}\left(\sum_{j=1}^{n} b_{k j}\right)},
\end{aligned}
$$

where $b_{i j}$ is an element of the Leontief inverse matrix.

\section{Results of VIOT analysis}

VIOT analysis will offer the total output multiplier that can indicate the inter-household purchases and sales of products in the village. This total output multiplier, as well as backward and forward linkages indices represents the degree of interdependency among households in the village. The main results of VIOT analysis by multipliers are as follows:

\subsection{Total output multiplier}

For any one household or a sector, a high level of intermediate inputs, e.g., those purchased from other households in the village, suggests strong linkages within economy and creates significant indirect effects in the output of supplying sectors. These effects are quantified by output multiplier. By employing Eq. (2), and Leontief inverse matrix table derived from VIOT constructed from our household survey data, as shown in

\footnotetext{
${ }^{5}$ For example, the results of the Leontief inverse matrix in the VIOT with the same matrix coefficients yield the same coefficient values (artificial) for backward linkage and forward linkage in some sectors; e.g. the backward coefficient of cattle, goat and duck in HH 01 is the same (5.654) as the forward linkage coefficient.
} 
Table 10 A numerical example of VIOT for Phonxay village

\begin{tabular}{|c|c|c|c|c|c|c|c|c|c|c|c|c|c|c|c|c|c|c|c|c|}
\hline \multirow{3}{*}{$\left.\right|_{\substack{\text { Purchases } \\
2}}$} & \multirow{3}{*}{ Sales' } & \multicolumn{11}{|c|}{\begin{tabular}{|l|} 
Intermediate Demand \\
\end{tabular}} & \multicolumn{7}{|c|}{\begin{tabular}{|l|} 
Final Demand \\
\end{tabular}} & \multirow{3}{*}{\begin{tabular}{|l}
$\begin{array}{l}\text { Total } \\
\text { output }\end{array}$ \\
\end{tabular}} \\
\hline & & \multicolumn{5}{|c|}{ HH 01} & \multirow{2}{*}{\begin{tabular}{|l|}
$\ldots$ \\
$\ldots$ \\
\end{tabular}} & \multicolumn{5}{|l|}{ HН 124} & \multicolumn{3}{|l|}{ HH 01} & \multirow[t]{2}{*}{\begin{tabular}{|l}
$\ldots$ \\
\end{tabular}} & \multicolumn{3}{|l|}{ HH 124} & \\
\hline & & Rice & $\begin{array}{l}\text { Crop } \\
\mathrm{s}\end{array}$ &.. & \begin{tabular}{|l|l|} 
NTFF \\
$\mathrm{s}$
\end{tabular} & \begin{tabular}{|l} 
Other \\
$\mathrm{s}$
\end{tabular} & & Rice & Crops & $\ldots$ & NTFPs & $\begin{array}{l}\text { Other } \\
\mathrm{s}\end{array}$ & CONS & INV & EXP & & CONS. & INV. & EXP. & \\
\hline \multirow{5}{*}{ HH 01} & Rice & 1350 & 0 & ... & 0 & 0 & $\ldots$ & 5 & 0 & $\ldots$ & 0 & 0 & 1150 & 100 & 0 & $\ldots$ & 1095 & 0 & 0 & 6150 \\
\hline & Crops & 0 & 75 & $\ldots$ & 0 & 0 & $\ldots$ & 0 & 0 & $\ldots$ & 0 & 0 & 215 & 20 & 28 & $\ldots$ & 0 & 0 & 0 & 513 \\
\hline & $\ldots$ & $\ldots$ & $\ldots$ & $\ldots$ & $\ldots$ & $\ldots$ & $\ldots$ & $\ldots$ & $\ldots$ & $\ldots$ & $\ldots$ & $\ldots$ & $\ldots$ & $\ldots$ & $\ldots$ & $\ldots$ & $\ldots$ & $\ldots$ & $\ldots$ & $\ldots$ \\
\hline & NTFPs & 0 & 0 & & 0 & 0 & $\ldots$ & 0 & 0 & $\ldots$ & 0 & 0 & 0 & 0 & 0 & $\ldots$ & 250 & 0 & 0 & 450 \\
\hline & \begin{tabular}{|l|} 
Others \\
\end{tabular} & 0 & 0 & ... & 0 & 0 & $\ldots$ & 0 & 0 & $\ldots$ & 0 & 0 & 0 & 0 & 0 & $\ldots$ & 0 & 0 & 0 & 0 \\
\hline$\ldots$ & $\ldots$ & $\ldots$ & $\ldots$ & $\ldots$ & $\ldots$ & $\ldots$ & $\ldots$ & $\ldots$ & $\ldots$ & $\ldots$ & $\ldots$ & $\ldots$ & $\ldots$ & $\ldots$ & $\ldots$ & $\ldots$ & 0 & 0 & 0 & \\
\hline \multirow{5}{*}{ HH 124} & Rice & 279 & 0 & $\ldots$ & 0 & 0 & $\ldots$ & 266260 & 0 & $\ldots$ & 0 & 0 & 921 & 0 & 0 & $\ldots$ & 3000 & 500 & 280500 & 651635 \\
\hline & Crops & 0 & 0 & $\ldots$ & 0 & 0 & & 0 & 824 & ... & 0 & 0 & 0 & 0 & 0 & $\ldots$ & 3716 & 150 & 3080 & 13895 \\
\hline & $\ldots$ & $\ldots$ & $\ldots$ & $\ldots$ & $\ldots$ & $\ldots$ & $\ldots$ & $\ldots$ & $\ldots$ & $\ldots$ & 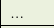 & $\ldots$ & $\ldots$ & $\ldots$ & $\ldots$ & $\ldots$ & $\ldots$ & $\ldots$ & $\ldots$ & $\ldots$ \\
\hline & \begin{tabular}{|l|} 
NTTPs \\
\end{tabular} & 0 & 0 & $\ldots$ & 0 & 0 & $\ldots$ & 0 & 0 & $\ldots$ & 57400 & 0 & 0 & 0 & 0 & $\ldots$ & 0 & 0 & 61100 & 118675 \\
\hline & Others & 0 & 0 & & 0 & 0 & $\ldots$ & 0 & 0 & $\mid \ldots$ & 0 & 0 & 0 & 0 & 0 & $\ldots$ & 0 & 0 & 0 & 0 \\
\hline \multirow{6}{*}{ VA } & Import & 0 & 250 & $\ldots$ & 0 & 0 & $\ldots$ & 128260 & 1350 & $\ldots$ & \begin{tabular}{|l|l|}
11190 \\
\end{tabular} & 0 & 44400 & 0 & 0 & 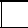 & 52250 & 198900 & 0 & 1673380 \\
\hline & \begin{tabular}{|l|} 
Wages \\
\end{tabular} & 0 & 150 & $\ldots$ & 0 & 200 & $\ldots$ & 7100 & 4660 & $\ldots$ & 1250 & 5420 & 0 & 0 & 0 & 0 & 0 & 0 & 0 & 98180 \\
\hline & \begin{tabular}{|l} 
Loans \\
\end{tabular} & 0 & 0 & \begin{tabular}{|l|}
$\ldots$ \\
\end{tabular} & 0 & 1100 & $\ldots$ & 0 & 0 & $\ldots$ & 0 & 0 & 0 & 0 & 0 & 0 & 0 & 0 & 0 & 173030 \\
\hline & Remittance & 0 & 0 & \begin{tabular}{|l}
.. \\
\end{tabular} & 0 & 150 & $\ldots$ & 0 & 0 & $\ldots$ & 0 & 0 & 0 & 0 & 0 & 0 & 0 & 0 & 0 & 33500 \\
\hline & \begin{tabular}{|l|} 
Surplus \\
\end{tabular} & \begin{tabular}{|l|l|}
4242 \\
\end{tabular} & 29 & $\ldots$ & 450 & -200 & & 249429 & 6239 & $\ldots$ & \begin{tabular}{|l|l|}
48835 \\
\end{tabular} & -5420 & 0 & 0 & 0 & 0 & 0 & 0 & 0 & 3416648 \\
\hline & \begin{tabular}{|l|l} 
Adjustment \\
\end{tabular} & 0 & 0 & $\ldots$ & 0 & -1250 & $\ldots$ & 0 & 0 & $\ldots$ & 0 & 0 & 0 & 0 & 0 & 0 & 0 & 0 & 0 & \begin{tabular}{|l|l|}
-304710 \\
\end{tabular} \\
\hline \multicolumn{2}{|l|}{ Total } & \begin{tabular}{|l|l|}
6150 \\
\end{tabular} & 513 & & 450 & 0 & $\ldots$ & 651635 & 13895 & $\ldots$ & 118675 & 0 & 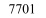 & $\begin{array}{l}120 \\
\end{array}$ & 28 & & 292601 & 453125 & 622130 & 11227853 \\
\hline
\end{tabular}

a Sales to other households along the top of the table from $\mathrm{HH} 1$ to $\mathrm{HH} 124$ in each row at the left of the table

b Purchases from other households at the left of the table by $\mathrm{HH} 1$ to $\mathrm{HH} 124$ in each column

Table 10, this VIOT produced a total output multiplier of 1.767. This multiplier can indicate the degree to which an individual household depends on other households for inputs and production in the village. Overall, this output multiplier (1.767) is not so high, and we couldn't conclude that the degree of interdependency among households in the village is weak or strong. ${ }^{6}$ The multiplier of 1.767 indicates that the village economy is dependent somewhat on the external economy than the internal economy for their inputs and production. The degree of interdependency would not result in large repercussions if agricultural improvement projects were implemented and promoted in the village. However, the interdependency among households in the village varies, as shown by the results of the backward linkage analysis and forward linkage analyses.

\subsection{Backward and forward linkages effects}

In this study, the backward and forward indices are estimated by employing Eqs. (3) and (4), respectively. These indices are used to indicate the degree of interdependence among households (sellers and buyers) in the village. The term forward linkage (as a seller) is used to indicate the interconnection of a seller to those buyers in the village (supply-side model). The backward linkage (as a buyer) is used to indicate the interconnection of a buyer to those sellers in the village economy (demand-driven side model). If the forward and backward values are smaller or bigger than one (1) they indicate a weak or strong degree of interdependence among households in the village, respectively. Moreover, if some products have both high forward and backward linkages values, it means that these products play important roles in economic development and growth.

Table 11 shows the results of forward linkages estimation from our VIOT. Surprisingly, the findings show that four rich households (HH 124, 122, 123, 121) are likely to have

\footnotetext{
${ }^{6}$ For example, the multiplier for Japan's IO table (2011), which includes 190 sectors, is 2.00; for the 2005 table for Japan, the multiplier is 1.99; both values are higher than that Phonxay village VIOT value. However, national IO tables tend to have higher multipliers than regional Io tables because each region primarily depends on outside areas for trading (that is, inflows, or imports, and outflows or exports). For example, the multiplier for Hiroshima IO table (2005), which includes 108 sectors, is 1.40, and the multiplier for the Shizuoka IO table (2000), which includes 188 sectors, is 1.30 . In contrast, the total output multiplier for the Singapore IO table (2010) is 1.60, which is smaller than that of the Phonxay VIOT.
} 
Table 11 Forward linkage values for major product transactions (indices). Source: author's calculation (March 8, 2017)

\begin{tabular}{|c|c|c|c|c|c|c|c|c|}
\hline No. & Seller ID & Rice & Seller ID & Crops & Seller ID & Cattles & Seller ID & Goats/pigs \\
\hline 1 & 124 & 4.936 & 121 & 2.512 & 116 & 3.392 & 97 & 1.979 \\
\hline 2 & 122 & 3.851 & 124 & 2.445 & 23 & 2.570 & 113 & 1.840 \\
\hline 3 & 123 & 3.225 & 122 & 1.947 & 122 & 1.402 & 122 & 1.800 \\
\hline 4 & 121 & 2.379 & 116 & 1.234 & 124 & 1.383 & 124 & 1.764 \\
\hline 5 & 118 & 0.887 & 123 & 1.215 & 119 & 1.009 & 67 & 1.696 \\
\hline 6 & 116 & 0.873 & 72 & 1.171 & 117 & 0.925 & 109 & 1.597 \\
\hline 7 & 47 & 0.842 & 118 & 1.169 & 118 & 0.855 & 101 & 1.566 \\
\hline 8 & 66 & 0.839 & 39 & 1.137 & 106 & 0.746 & 93 & 1.562 \\
\hline 9 & 86 & 0.832 & 20 & 1.131 & 111 & 0.720 & 89 & 1.427 \\
\hline 10 & 93 & 0.826 & 112 & 1.070 & 123 & 0.691 & 114 & 1.417 \\
\hline 11 & 77 & 0.814 & 114 & 0.984 & 121 & 0.676 & 62 & 1.330 \\
\hline 12 & 74 & 0.812 & 11 & 0.979 & 86 & 0.672 & 94 & 1.330 \\
\hline 13 & 103 & 0.805 & 43 & 0.969 & 60 & 0.651 & 72 & 1.311 \\
\hline 14 & 102 & 0.803 & 29 & 0.957 & 96 & 0.633 & 112 & 1.304 \\
\hline 15 & 59 & 0.801 & 113 & 0.922 & 108 & 0.611 & 120 & 1.289 \\
\hline 16 & 70 & 0.799 & 52 & 0.911 & 112 & 0.607 & 119 & 1.231 \\
\hline 17 & 33 & 0.796 & 25 & 0.897 & 87 & 0.582 & 117 & 1.280 \\
\hline 18 & 79 & 0.790 & 78 & 0.894 & 99 & 0.565 & 102 & 1.229 \\
\hline 19 & 78 & 0.788 & 35 & 0.889 & 104 & 0.565 & 110 & 1.182 \\
\hline 20 & 71 & 0.786 & 80 & 0.887 & 110 & 0.565 & 123 & 1.049 \\
\hline No. & Seller ID & Duck & Seller ID & Chicken & Seller ID & Bamboo & Seller ID & NTFPs \\
\hline 1 & 57 & 5.449 & 124 & 2.717 & 101 & 2.375 & 115 & 3.957 \\
\hline 2 & 97 & 3.251 & 113 & 1.964 & 115 & 2.271 & 117 & 3.057 \\
\hline 3 & 46 & 2.827 & 38 & 1.696 & 122 & 1.861 & 118 & 2.921 \\
\hline 4 & 121 & 2.674 & 119 & 1.687 & 98 & 1.734 & 123 & 2.191 \\
\hline 5 & 113 & 2.647 & 47 & 1.631 & 97 & 1.718 & 121 & 1.931 \\
\hline 6 & 25 & 2.169 & 116 & 1.600 & 120 & 1.553 & 05 & 1.593 \\
\hline 7 & 03 & 2.136 & 117 & 1.577 & 124 & 1.519 & 15 & 1.555 \\
\hline 8 & 116 & 1.984 & 56 & 1.573 & 121 & 1.422 & 90 & 1.508 \\
\hline 9 & 112 & 1.729 & 77 & 1.535 & 108 & 1.329 & 116 & 1.470 \\
\hline 10 & 77 & 1.696 & 107 & 1.519 & 113 & 1.325 & 113 & 1.445 \\
\hline 11 & 92 & 1.625 & 120 & 1.485 & 39 & 1.214 & 92 & 1.413 \\
\hline 12 & 114 & 1.561 & 109 & 1.479 & 123 & 1.143 & 83 & 1.385 \\
\hline 13 & 14 & 1.513 & 58 & 1.435 & 116 & 1.129 & 40 & 1.272 \\
\hline 14 & 53 & 1.476 & 76 & 1.392 & 90 & 1.112 & 34 & 1.244 \\
\hline 15 & 70 & 1.461 & 54 & 1.364 & 104 & 1.056 & 78 & 1.244 \\
\hline 16 & 81 & 1.445 & 97 & 1.336 & 68 & 0.975 & 25 & 1.225 \\
\hline 17 & 33 & 1.422 & 121 & 1.368 & 26 & 0.953 & 37 & 1.208 \\
\hline 18 & 117 & 1.409 & 115 & 1.308 & 72 & 0.918 & 17 & 1.194 \\
\hline 19 & 31 & 1.348 & 123 & 1.239 & 91 & 0.905 & 122 & 1.176 \\
\hline 20 & 120 & 1.331 & 112 & 1.171 & 118 & 0.902 & 124 & 1.095 \\
\hline
\end{tabular}

The third column shows the values of forward linkage effects of each product by VIOT analysis

high forward linkages values for all product transactions such as rice, livestock, crops, and bamboo transactions in the village. This means that these four rich households are the main suppliers in the village. For instance, in rice transactions, these four households are key sellers, and especially the transactions among them are stronger than among 
other poor and non-poor households. In particular, $\mathrm{HH} 124$ with a forward linkage value of 4.936, which is highest among top 20 rice sellers in the village, while HH 121 with a forward linkage value of 2.512 is the highest among top 20 crops sellers in the village, HH 57 with a forward linkage value of 5.449 is the highest among top 20 duck sellers, HH 116 with a forward linkage value of 3.392 is the highest among top 20 cattle sellers, $\mathrm{HH} 124$ with a forward linkage value of 2.717 is the highest among top 20 chicken suppliers, and HH 115 with a forward linkage value of 3.957 is the highest among top 20 NTFPs sellers in the village, respectively. The main findings from Table 10 show that the key players in the village are those four rich households, who are playing a major role in transactions, they tend to sell more their products to other households in the village.

In contrast, Table 12 shows the results of backward linkages estimation from our VIOT. In overall, our findings show that most of the poor households are likely to have high backward linkages values for major transactions such as duck, chicken, bamboo, crops, and rice transactions in the village. This means that these poor households are the main buyers in the village. For instance, HH 86, HH 47, HH 74, HH 102, and HH 66, are the main rice buyers, while $\mathrm{HH} 20,47,77,57$, and 37 are the main duck buyers in the village. The rice transactions between these households and other households are very common in the village. The backward linkage analysis finds a strong degree of interdependence among the poor and non-poor counterparts in duck and chicken transactions. More specifically, we find that HH 86 with a backward linkage value of 1070, which is highest among top 20 rice buyers in the village, while HH 57 with a backward linkage value of 3715 is the highest among top 20 duck buyers, and HH 20 with a backward linkage value of 1696 is the highest among top 20 chicken buyers in the village, respectively. The findings from Table 11 show that the key buyers in the village are those who are poor and some non-poor households in the village. They therefore tend to buy more products from other non-poor households, who are also playing roles in village transactions.

The following conclusions can be drawn from these results:

Interdependency between households tends to be stronger in transactions among high-income households (the four rich families from HH121 to HH124) in any transaction.

For rice transactions such as rice dusk, and rice grain, in particular, the degree of interdependency between high-income households is strong: households that strengthen their interdependency through direct transactions involving rice are likely to be highincome households rather than low-income households.

Lower/middle-income households and high-income households depend on transactions involving other foods, such as other crops and bamboo. The main suppliers in other crop transactions are high-income households, while many lower/middle-income households are purchasers. In bamboo transactions, lower/middle-income households are both sellers and buyers, but many lower/middle-income households are also suppliers, which may indicate that lower/middle-income households sell bamboo to buy other crops within the village.

Transactions involving relatively expensive products, such as duck and chicken, seem to be active between lower/middle-income households and higher-income households. In these transactions concerning domestic animals, a common feature is that the main suppliers are almost always high-income households, while many lower/middle-income 
Table 12 Backward linkage values for major product transactions (indices). Source: author's calculation from VIOT (March 8, 2017)

\begin{tabular}{|c|c|c|c|c|c|c|c|c|}
\hline No. & Buyer ID & Rice & Buyer ID & Crops & Buyer ID & Cattles & Buyer ID & Goats/pigs \\
\hline 1 & 86 & 1.070 & 87 & 1.375 & 115 & 5.654 & 97 & 1.979 \\
\hline 2 & 47 & 1.041 & 27 & 1.365 & 116 & 3.392 & 62 & 1.754 \\
\hline 3 & 74 & 1.034 & 73 & 1.364 & 23 & 2.926 & 93 & 1.695 \\
\hline 4 & 102 & 1.029 & 90 & 1.310 & 60 & 1.352 & 109 & 1.693 \\
\hline 5 & 123 & 1.021 & 34 & 1.287 & 86 & 1.290 & 72 & 1.687 \\
\hline 6 & 66 & 1.019 & 83 & 1.246 & 117 & 0.925 & 94 & 1.678 \\
\hline 7 & 70 & 0.991 & 20 & 1.237 & 118 & 0.842 & 32 & 1.567 \\
\hline 8 & 93 & 0.988 & 72 & 1.171 & 119 & 0.799 & 101 & 1.566 \\
\hline 9 & 75 & 0.986 & 48 & 1.159 & 109 & 0.746 & 114 & 1.453 \\
\hline 10 & 78 & 0.977 & 85 & 1.157 & 111 & 0.720 & 89 & 1.427 \\
\hline 11 & 59 & 0.966 & 101 & 1.144 & 122 & 0.701 & 28 & 1.408 \\
\hline 12 & 124 & 0.957 & 31 & 1.119 & 123 & 0.690 & 71 & 1.362 \\
\hline 13 & 02 & 0.954 & 71 & 1.111 & 121 & 0.675 & 66 & 1.360 \\
\hline 14 & 122 & 0.953 & 86 & 1.089 & 87 & 0.582 & 29 & 1.306 \\
\hline 15 & 121 & 0.947 & 29 & 1.058 & 120 & 0.581 & 102 & 1.294 \\
\hline 16 & 30 & 0.945 & 36 & 1.025 & 113 & 0.568 & 35 & 1.290 \\
\hline 17 & 73 & 0.939 & 97 & 1.015 & 62 & 0.565 & 39 & 1.210 \\
\hline 18 & 77 & 0.934 & 96 & 1.008 & 70 & 0.565 & 110 & 1.182 \\
\hline 19 & 110 & 0.931 & 40 & 1.000 & 103 & 0.565 & 99 & 1.131 \\
\hline 20 & 71 & 0.928 & 84 & 0.995 & 109 & 0.565 & 82 & 1.068 \\
\hline No. & Buyer ID & Duck & Buyer ID & Chicken & Buyer ID & Bamboo & Buyer ID & NTFPs \\
\hline 1 & 57 & 3.715 & 20 & 1.696 & 101 & 2.374 & 115 & 3.957 \\
\hline 2 & 97 & 3.251 & 47 & 1.593 & 115 & 2.268 & 117 & 3.057 \\
\hline 3 & 46 & 2.827 & 107 & 1.585 & 120 & 1.854 & 118 & 2.921 \\
\hline 4 & 50 & 2.714 & 108 & 1.542 & 98 & 1.734 & 123 & 2.191 \\
\hline 5 & 03 & 2.136 & 77 & 1.535 & 97 & 1.696 & 121 & 1.931 \\
\hline 6 & 14 & 1.819 & 57 & 1.522 & 122 & 1.627 & 05 & 1.593 \\
\hline 7 & 77 & 1.696 & 56 & 1.508 & 108 & 1.329 & 15 & 1.555 \\
\hline 8 & 92 & 1.625 & 109 & 1.479 & 124 & 1.277 & 90 & 1.508 \\
\hline 9 & 25 & 1.583 & 37 & 1.478 & 121 & 1.269 & 116 & 1.470 \\
\hline 10 & 33 & 1.546 & 92 & 1.472 & 39 & 1.245 & 113 & 1.445 \\
\hline 11 & 31 & 1.481 & 106 & 1.471 & 113 & 1.216 & 92 & 1.413 \\
\hline 12 & 09 & 1.447 & 58 & 1.435 & 116 & 1.131 & 83 & 1.385 \\
\hline 13 & 81 & 1.445 & 97 & 1.423 & 104 & 1.123 & 40 & 1.272 \\
\hline 14 & 53 & 1.441 & 70 & 1.411 & 90 & 1.121 & 34 & 1.244 \\
\hline 15 & 70 & 1.426 & 44 & 1.388 & 123 & 1.090 & 25 & 1.225 \\
\hline 16 & 40 & 1.422 & 26 & 1.377 & 118 & 1.044 & 37 & 1.208 \\
\hline 17 & 121 & 1.421 & 54 & 1.364 & 68 & 1.033 & 17 & 1.194 \\
\hline 18 & 07 & 1.417 & 18 & 1.358 & 26 & 0.965 & 122 & 1.176 \\
\hline 19 & 90 & 1.411 & 33 & 1.352 & 119 & 0.935 & 20 & 1.171 \\
\hline 20 & 18 & 1.409 & 43 & 1.176 & 72 & 0.912 & 119 & 1.158 \\
\hline
\end{tabular}

The third column shows the values of backward linkage effects of each product by VIOT analysis

households are on the demand side. In duck transactions in particular, many buyers are lower-income households, although the number of transactions is not very large. Considering this finding and the results described in (3) above, lower/middle-income 
households may tend to buy expensive goods within the village, and not from outside it. Thus, expensive goods (e.g., cattle) are the main products outside the village.

Overall, the interdependency of the four richest families in this village through direct transactions is very strong, while there are few transactions among lower-income households. These results indicate that transactions involving relatively cheap goods (e.g., rice) mainly generate strong interdependency among the four higher-income families, while the degree of interdependency among lower-income households is weak. Transactions involving relatively expensive goods (e.g., duck and chicken) between higher-income households and lower/middle-income households are strong. In addition, we can easily imagine that the four higher-income households that work as traders in the village gain large profits from the price gap between the village price and the market price. The estimation of exactly how much these four rich households obtain in profits after considering transportation costs and savings costs for goods is difficult, but this difference in interdependency and roles between the four rich families and other households could be a structural cause of the huge income gap in this village.

\section{Concluding remarks}

This paper describes the trial application of village input-output table (VIOT) construction from household survey data obtained from northern part of Lao PDR for 2016. The conversion of household data to an input-output (IO) framework provides information about inter-household trade data; in particular, material and monetary flows in a rural village can show reciprocity not only among key agents (traders), but also among poor households.

The results presented in this paper revealed the strength of interdependency between households in the rural village of Phonxay in Luang Prabang province of Lao PDR. Our VIOT contained all 124 households, with nine plus one items in each household, forming a matrix with a size of $1240 \times 1240$. The main findings of this work are as follows:

1. The VIOT analysis yielded a total output multiplier of 1.767 . This number is absolutely low, suggesting that the village economy shows greater dependence on the external economy than the village's own economy for its production and livelihood.

2. Backward and forward linkage analyses indicated that transactions involving rice between the four highest-income households are strong.

3. Transactions involving relatively expensive goods (e.g., duck and chicken) are frequent between higher-income households and lower/middle-income households, indicating that lower/middle-income households tend to buy these goods from higher-income households, rather than from outside the village.

4. Interdependency in transactions involving any good is strong among higher-income households, and particularly the four wealthiest families from HH121 to HH124, than among lower/middle-income households.

5. The four higher-income households, which play the role of intermediate traders in the village, most likely gain large profits from the price gap between the village and the market prices.

6. The different roles of the higher-income households and lower-income households are a structural cause of the huge income gap in the village. 
These results support an economic policy aimed at enhancing marketing in the region to identify who are the key traders, as well as producers and consumers in this village economy. For many villagers, it is crucial to create opportunities to participate in trade activity. To do so, infrastructure such as that promoting production, supplying electricity and water, roads and education is necessary. Furthermore, key economic sectors, such as livestock activity, could provide villagers with more opportunities to improve their incomes and enhance their trade networking and market expansion inside and outside the village. This division of labor between key agents in the village may enhance the productivity of the village. Deepening trade and social networks among the households in this village should be improved to enhance socio-economic development in the region. This study represents the first application of a VIOT based on micro-household survey data from a poor rural area of Lao PDR, a developing country.

\section{Acknowledgements}

We are grateful to all collaborators and advisors, anonymous referees and editors of the journal for their useful and constructive comments to revise this article.

\section{Authors' contributions}

We designed the study and conducted the household survey in a disadvantaged village in northern Lao PDR with the cooperation of the government officials from Trade and Industry Office of Ngoi district of Luang Prabang province, Lao PDR in 2015 and 2016. Data entry and quality check were done in Hiroshima University. The analysis and interpretation of the data including findings were done by all authors. All authors revise the final manuscript. All authors read and approved the final manuscript.

\section{Funding}

This research was financially supported by a grant-in-aid from the Zengin Foundation for Studies on Economics and Finance in 2016 and Japan Society for the Promotion of Science (JSPS) KAKENHI [Grant Number JP 16 H05704].

\section{Availability of data and materials}

The datasets supporting the findings of this study are available from the corresponding author upon reasonable request.

\section{Competing interests}

The authors declare that they have no competing interests.

\section{Author details}

'Graduate School for International Development and Cooperation, Hiroshima University, 1-5-1 Kagamiyama, Higashi-Hiroshima, Hiroshima 739-8529, Japan. ${ }^{2}$ Graduate School of Humanities and Social Sciences, Hiroshima University, 1-1-1 Kagamiyama, Higashi-Hiroshima, Hiroshima 739-8524, Japan. ${ }^{3}$ School of Economics and Management, Kochi University of Technology, 2-22 Eikokuji, Kochi 780-8515, Japan. ${ }^{4}$ Research Institute for Future Design, Kochi University of Technology, 2-22 Eikokuji, Kochi 780-8515, Japan.

Received: 27 November 2018 Revised: 30 March 2020 Accepted: 12 December 2020

Published online: 12 January 2021

\section{References}

Agaje TF (2008) Growth linkages and policy effects in a village economy in Ethiopia: analysis of interactions using a social accounting matrix (SAM) framework. Department of Economics, Faculty of Applied Economics, University of Antwerp, Belgium

Chenery HB, Watanabe T (1958) International comparisons of the structure of production. Econometrica 26:487-521

Ćmiel A, Gurgul H (2002) Key sector analysis based on input-output tables. Syst Sci 28(3):95-113

Cristobal SJR, Biezma MV (2006) The mining industry in the European Union: analysis of inter-industry linkages using input-output analysis. Resour Policy 31(2006):1-6

Defourny J, Thorbecke E (1984) Structural path analysis and multiplier decomposition within a social accounting framework. Econ J 94:111-136

Dietzenbacher E, Los B, Stehrer R, Timmer MP, de Vries GJ (2013) The construction of world input-output tables in the WIOD project. Econ Syst Res 25(1):71-98

Faße A, Grote U (2014) Bioenergy and rural development: the role of agroforestry in a Tanzanian village economy. Ecol Econ 106:155-166

Gurgul H, Majdosz P (2005) Key sector analysis: a case of the transited Polish economy. Manag Glob Transit 3(1):95-111

Gurgul H, Lach L (2015) Key sectors in the post-communist CEE economies: what does transition data say? Communist Post-Communist Stud 48(2015):15-32

Gurgul H, Lach L (2016) Simulating evolution of interindustry linkages in endogenous dynamic IO model with layers of techniques. Metroeconomica 67(2016):632-666 
Gurgul H, Lach L (2018) Some remarks on a social network approach to identifying key sectors. Econ Syst Res 30(1):120-135

Hewings GJD (1982) The empirical identification of key-sectors in an economy: a regional perspective. Dev Econ 20:173-195

Hewings GJD, Romanos MC (1981) Simulating less developed regional economies under conditions of limited information. Geogr Anal 13(4):373-390

Hirschman AO (1958) Interdependence and industrialization. In: Hirschman AO (ed) The strategy of economic development. Yale University Press, New Haven

Isard W (1951) Interregional and regional input-output analysis: a model of a space-economy. Rev Econ Stat 33(4):318-328

Lewis B, Thorbecke E (1992) District-level economic linkages in Kenya: evidence based on a small regional social accounting matrix. World Dev 20:881-897

San Martin O, Holden M (2004) Food and tree in the village-economic development strategies based on food production and forest resources: a social accounting matrix analysis. Paper to be presented at the conference "Input-output and general equilibrium modelling: data, modelling and policy analysis". Brussels

Subramanian A, Qaim M (2009) Village-wide effects of agricultural biotechnology: the case of BT cotton in India. World Dev 37(1):256-267

Taylor JE, Adelman I, Golan EH (1996) Village economies: the design, estimation, and use of village wide economic models. Cambridge University Press

Temurshoev U, Oosterhaven J (2014) Analytical and empirical comparison of policy-relevant key sector measures. Spat Econ Anal 9(3):281-308

The Prime Minister of Lao PDR. Decree on Poverty and Development Standard 2010 to 2015, No. 285/PO, dated $13 / 10 / 2009$

Zhang Z et al (2015) The compilation of China's interregional input-output model 2002. Econ Syst Res 27(2):238-256

\section{Publisher's Note}

Springer Nature remains neutral with regard to jurisdictional claims in published maps and institutional affiliations.

\section{Submit your manuscript to a SpringerOpen ${ }^{\odot}$ journal and benefit from:}

- Convenient online submission

- Rigorous peer review

- Open access: articles freely available online

- High visibility within the field

Retaining the copyright to your article

Submit your next manuscript at $\gg$ springeropen.com 